\title{
Baltijas jautājums lielvalstu politikā
}

\author{
Recenzija par grāmatu: Kaarel Piirimäe. Roosevelt, Churchill, \\ and the Baltic Question. Allied Relations during the Second World War. \\ Palgrave Macmillan, 2014, 256 p. ISBN 978-113-7442-36-9
}

\section{Eduards Bruno Deksnis}

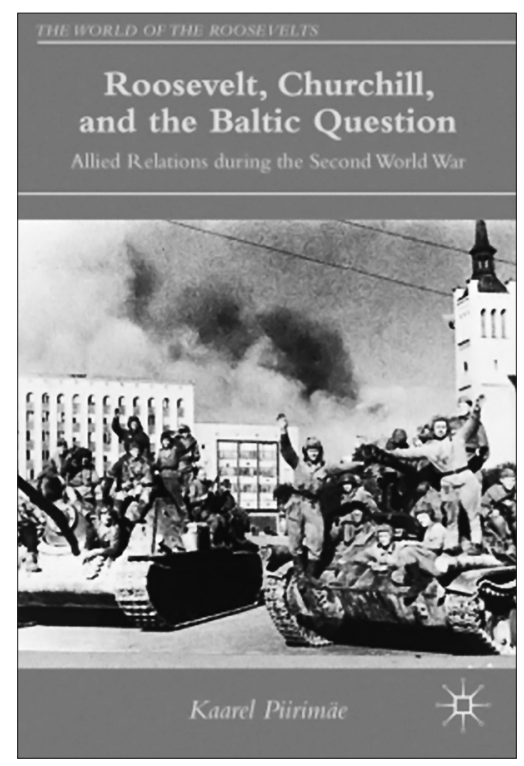

Grāmatas autors Kārels Pīrimē (Kaarel Pïrimäe), kurš dzimis 1979. gadā, uzaudzis un dzīvo Igaunijā, ir profesionāli saistīts ar Baltijas Aizsardzības koledžu (Baltic Defence College), kur ir profesors, un arī ar Tartu Universitāti (pētnieks Vēstures fakultātē); daudzu rakstu autors un rakstu krājumu sastādītājs, regulāri publicējas žurnālos Ajalooline Ajakiri un Diplomaatia. Pēc studijām Sv. Jāņa koledžā (St John's College, Cambridge) atradis finansiālu atbalstu, lai publicētu savu doktora disertāciju grāmatu sērijā, kas veltīta ASV prezidenta Franklina Delano Rūzvelta (Franklin Delano Roosevelt) politiskās karjeras dažādām šḳautnēm. Tas viṇa pētījumam par traucējošo Baltijas jautājumu nodrošinājis vēl nebijušu redzamību pasaules mērogā. Vairākas šis monogrāfijas recenzijas jau parādījušās angḷ valodā. ${ }^{1}$ Šìs recenzijas autora meklējumi liecina par grāmatas visai minimālo atpazīstamību Latvijas akadēmisko pētnieku aprindās. ${ }^{2}$

Monogrāfijā nav atrodams mēǵinājums pārskatīt Rietumu sabiedroto pien,emtos lēmumus par Baltijas valstīm, drīzāk apskatìts fons, 
ierēdniecisko un politisko personību privāti paustie uzskati, kas neapšaubāmi iekrāsoja sarunu gaitu. Sarunu diplomātiskās nianses izvērtētas un to kontekstualizācija veikta, izvairoties no atpakaļejoša skatījuma. Izmantots l,oti plašs primāro dokumentu spektrs, ieskaitot daudzu otrā ranga sarunu vedēju, arī iesaistīto ierēdṇu, arhīvu materiālus. Īpaši uzteicams ir l, loti lielais aplūkoto primāro dokumentu skaits, no tiem daudzi atrasti tādos arhīvos, kas parasti netiek apmeklēti: Vinstona Čērčila (Winston Churchill), arī tā laika Lielbritānijas ārlietu ministra, Antonija İdena (Anthony Eden) un publicista Eduarda Kāra (Edward Hallett Carr) arhīvā Lielbritānijā, ASV prezidenta Rūzvelta arhīvā, arī ASV ierēdṇu arhīvos, kas atrodas Prinstonas (Princeton) Universitātes Mudd bibliotēkā (5. lpp.). K. Pīrimē arī bijusi izdevība ieskatīties Vjačeslava Molotova 82. fonda materiālos Krievijas Valsts sociāli politiskās vēstures arhīvā (Rossijskij gosudarstvennyj arhiv social'no-politicheskoj istorii (RGASPI)). Darbā izmantoti Krievijā nesen publicētie dokumentu apkopojumi. ${ }^{3}$ Loti bagātīgais un daudzpusīgais sekundāro (t. sk. avižu) avotu uzskaitījums papildina primāro avotu sniegto informāciju, lai veicinātu notikumu nepieciešamo kontekstualizāciju. Nav ignorēti nesenie Rietumu autoru centieni attaisnot PSRS rīcību Baltijas valstīs 1939.-1941. gadā un arī pēc tam.

Monogrāfijai ir deviņas nodaḷas, neskaitot ievadu un secinājumus. Šinī recenzijā tiks izcelti izmantotie dokumenti, kas, šķiet, līdz šim maz ievēroti Latvijas pētnieku darbos, bet netiks apskatīta viena nodaḷa, kas veltīta ASV plāniem par iespējamo pēckara valstisko konfigurāciju Eiropā. Galvenokārt skatīta ASV Valsts departamenta plānošanas grupas (Advisory Committee on Postwar Foreign Policy) darbība. Daudziem pieaicinātiem ekspertiem, padomu devējiem aksiomātiska bija nostāja, ka Baltijas valstis bijušas par mazām, lai pastāvētu (ieskaitot deklarāciju, ka to iedzīvotāji jau 1940. gadā to sapratuši, 85. lpp.), bet kāds ASV dzīvojošais balto krievu emigrants izteicies, ka "Baltijas valstu iedzivotāji momentā balsotu par pievienošanos Krievijai, ja pēdejjā tiktu gāzta padomju vara" (84. lpp.). Savukārt ASV ierēdṇi nenoticēja šādām nostādnēm, tomēer, saprotot ASV prezidenta Rūzvelta intereses trūkumu, ziņojumos tikai starp citu izteicās par Baltijas jautājumu.

\section{Neatkarības zaudēšana, Lielbritānijas un ASV attieksme pret inkorporāciju PSRS sastāvā}

Pirmās trīs nodaḷas ir veltītas Baltijas valstu okupācijai (ar uzsvaru uz Igaunijas Republikas pieredzi) un divu pasaules lielvaru - Lielbritānijas un ASV - nedaudz atšḳirīgai, toties visumā vārgi nosodošajai reakcijai uz notikumiem. Arī citviet monogrāfijā autors uzsvēris Rietumos palikušo igauṇu diplomātu rīcības un viṇu sarakstē pausto tā laika situācijas novērtējumu. Ar Baltijas diplomātu svītrošanu no Lielbritānijas diplomātiskās listes viṇi zaudēja tiesības pieprasīt satikšanos ar Lielbritānijas valsts sekretāru ārlietās; viniiem nācās samierināties ar iesniegumiem un sarunām ar ārlietu resora (Foreign Office) ierēdņiem. Gods godam monogrāfijā atzīmēta un izcelta Lietuvas diplomāta Povila Žadeiķa (Povilas Žadeikis) saruna ar Luisu Hendersonu (Loy Henderson) 1940. gada 22. jūnijā un vēlāk L. Hendersona tikšanās ar Alfrēdu Bīlmani (datums nav minēts) - tā bija dzirkstele ugunskuram, kas izpaudās kā slavenā 1940. gada 23. jūlija ASV Vellesa deklarācija. Autors pievērš uzmanību dažām deklarācijas īpatnībām: tā tika publicēta presē; PSRS netika nosaukta vārdā; tā piesauca arī ASV daudzinātās vērtības - padarot to imūnu pret atcelšanu. Recenzents uzskata, ka deklarācija tika saistīta ar ASV prezidenta Rūzvelta personību un tādējādi 
viņa reputācijas aptraipīšanu - tāda rīcība pat mūsdienās prasītu rēkināties ar lielu politisku pretdarbību.

Monogrāfijas autors izceḷ būtisko faktu, ka gan Lielbritānijā, gan ASV glabājās Baltijas valstu zelta depozīti nopietnā apjomā, pēc tiem PSRS snaikstījās jau pirmajās dienās pēc Baltijas valstu okupācijas. Abas valstis, iesaldējot līdzekḷus, to darīja ar nodomu iegūt no PSRS kompensācijas par savu valstspiederīgo īpašumu un līdzekḷu konfiscēšanu. Savos pētījumos monogrāfijas autors nav atradis pierādījumu, ka ASV Valsts departamentā būtu pastāvējusi konsolidēta "Rīgas grupa"., 5 Abu valstu pieredze bija pierādījusi, ka PSRS neatzina ārzemnieku (fizisko un juridisko personu) tiesības uz kompensāciju par viṇu nacionalizētajiem (konfiscētajiem) ipašumiem. ${ }^{6}$ Ideja, ka šìs valstis brīvprātīgi nodotu PSRS reālus finanšu instrumentus, bija tik absurda, ka jājautā, cik apķērīgi bija PSRS Narkomindel (Ārlietu tautas komisariāts) kadri, kas cerēja uz šādu laupiš̌anu. ASV - kas neiesaistījās karadarbībā līdz 1941. gada decembrim - arī tika atkārtoti mudinātas, sākot ar 1940. gada vasaru līdz 1941. gada jūnijam, atteikties no neatzišanas politikas - ko tās noraidīja (40. lpp.). Īpaši centīgs PSRS protestu paudējs bija tā laika PSRS vēstnieks ASV Konstantīns Umanskis (Konstantin Umanskij), kas, analizējot ASV Baltijas valstu neatkarības atzīšanas tekstu, saprata, ka ASV uzskata Baltijas valstis par Krievijas sastāvdaḷu (40.-41. lpp.).

\section{Lielās alianses izveidošanās un rīcība līdz Jaltas konferencei 1944. gadā}

Lielbritānija, sākot ar 1940. gada jūniju, bija viena karā ar Vāciju (tās bruṇoto spēku evakuācija, lai tie nekristu Vācijas gūstā, noslēdzās 1940. gada jūnija pirmajās dienās). Likumsakarīgi tika meklēts sabiedrotais - PSRS, kas, lai arī cik odiozi uzvedās, gan uzbrūkot Somijai, gan okupējot dậu Polijas, bija vienīgais potenciālais militārais spēks. Pirmā misija saistās ar diezgan ekstrēmu politisku uzskatu personas, Steforda Kripsa (Stafford Cripps ${ }^{7}$ ), iecelšanu par Lielbritānijas sūtni PSRS. Kripss angažēti aǵitēja par Baltijas valstu aneksijas de iure atzī̌̌anu kā priekšnoteikumu eventuālai aliansei ar PSRS; Lielbritānijas valdība noraidỉja šādu darbību pret apsolìto rīcību nākotnē (29. lpp.).

Neapšaubāmi interesantas ir PSRS un Lielbritānijas divpusējās sarunas, kas aizsākās 1941. gada 16. decembrī ar Stalina prasību atzìt 1941. gada robežas formālā līgumā. Jau pirms šiem pirmajiem augsta līmeṇa kontaktiem Lielbritānijas ārlietu resors bija brīdinājis, ka PSRS mērksos ietilpst Baltijas valstu un Somijas iekḷaušana PSRS sastāvā (8. un 59. lpp.). Sarunas turpinājās, PSRS prasībām pieaugot līdz pat Polijas rietumu robežu atzǐšanai. A. İdens atkārtoti deva signālus par piekrišanu Baltijas valstu gadījumā, taču Polijas jautājumā viņš bija rezervēts. Tomēr Stalins pēkšņi un negaidīti, praktiski no vienas dienas uz otru, 1942. gada 24. maijā pārsteidza PSRS sarunu vedējus, atteikdamies pieminēt Baltijas valstu statusu noslēgtajā līgumā. Izskaidrojumi, kas monogrāfijā izteikti, ir jau daudzviet tiražēti (75. un 76. 1pp.); viennozīmīgs Stalina rīcības izskaidrojums līdz šim nav izvirzìts. Autors tos papildina ar hipotēzi, ka Stalıinam de iure atzišana nebija būtisks šḳērslis viṇa rīcībai. Viṇš norāda, ka Igaunijas diplomāti pārspīlēja šī iznākuma nozìmi un bija nepatīkami pārsteigti ar Lielbritānijas 1942. gada 5. jūnija lēmumu izslēgt Baltijas diplomātu vārdus no diplomātiskās listes (77. lpp.).

Pēc tam, kad ASV iesaistījās karadarbībā, Eiropā aizsākās trīspusīgas sarunas, toties ASV militāri tehniskais potenciāls un PSRS nepieciešamā tehniskā palīdzība sarunas de facto pārvērta par gandrīz ekskluzīvi divpusējām ASV un PSRS sarunām. 
Baltijas valstu statuss nebija galvenā tēma šinīs sarunās. Vācijas armijas kapitulācija pie Staḷingradas 1943. gada februārī pārliecināja Rietumu sabiedrotos, ka PSRS sāks vāciešu iebrucējus izdzìt no savas teritorijas. Pretuzbrukums, ticams, vismaz aizies līdz Vācijas galvaspilsētas ieņemšanai (varbūt arī tālāk), nacistu režīma iznīcināšanai un aizvietošanai. Rietumu sabiedrotie un PSRS trīspusīgās sarunās Teherānā 1943. gada novembrī un decembrī vienojās par operatīviem 1944. gadā sasniedzamiem mērķiem, ieskaitot Rietumu iebrukumu okupētās Eiropas rietumos, lai liegtu PSRS krist kārdinājumā "atbrīvot" Rietumeiropas valstis. Jau 1944. gada pavasarī ASV bez ierunas privāti bija piekāpusies Baltijas valstu jautājumā. Martā satiekoties ar A. İdenu, prezidents Rūzvelts bija pieņēmis Baltijas valstu inkorporāciju PSRS, protams, pēckara apstākḷos (102. lpp.). Viṇa paustā iecere izmantot Baltijas valstu de iure atzīšanu, "tirgojoties" ar PSRS, bija vairāk nekā naiva (104. lpp.). Stalịns jau laikus bija informēts (pateicoties saviem specdienestiem) par ASV pozīciju Teherānas sarunās par PSRS robežām (112. lpp.) un varēja izspēlēt erudītus argumentus attiecībā uz Baltijas valstīm kā neatņemamām Krievijas teritorijām. Novērtējot tā laika Baltijas diplomātu tālāko rīcību, jāievēro, ka vienošanās par Baltijas valstīm bija slepena.

Prezidentam Rūzveltam nebija nekādu personīgu simpātiju pret Baltijas valstu iedzīvotājiem, to privāti viņš izteica diezgan bieži, ieskaitot sarunas ar PSRS ārlietu tautas komisāru (ministru) Maksimu Litvinovu (Maksim Litvinov) jau 1942. gada martā. L,itvinova dienesta ziṇojumā ASV prezidenta faktiskā pozīcija izteikta šādi: “ASV un mums ir identiska pozicija, un neiebilst atzit mūsu pirmskara [1941. gada] robežas [...] [Rūzvelts] uzskata, ka Baltijas provinces kḷūdaini atdalijāas no Krievijas pēc Pirmā pasaules kara." Tomēr Rūzvelta nevēlēšanās rakstiski apstiprināt šādu nostāju, pat slepenas rakstiskas vienošanās veidolā, pirms kara beigām padarīja Litvinovu uzmanīgu (71. lpp.). Saskarsme ar ASV diplomātiju rāda, ka ASV aicinājums sarunu partneru pusēm izskatīt jautājumu vēlāk nereti noved pie sarunām, kurās mutvārdu vienošanās netiek uzskatītas par saistošām. Velti spekulēt, kāda būtu bijusi pēckara notikumu evolūcija, ja prezidents Rūzvelts būtu izmantojis savu četrgadīgo valdīšanas mandātu, ko ieguva 1944. gada prezidenta vēlēšanās.

Pēc savu prasību gandrīz pilnīgas apmierināšanas Teherānas konferencē 1944. gadā PSRS izvērsa apbrīnojami izturētu publiskas diplomātijas kampaṇu, lai izdzēstu domu, ka Baltijas valstīm bija jebkāda leǵitīma identitāte kā Krievijas provincēm, respektīivi, padomju republikām. Ievērības cienīga monogrāfijā ir analīze par idejisko simbiozi, kas izveidojās starp Justu Palecki (Justas Paleckis, 1899-1980) (Lietuvas PSR Augstākās padomes Prezidija priekšsēdētājs, 1940-1967) un ASV publicistu Valteru Lipmanu (Walter Lippmann, 1889-1974) (120. lpp.). Cits izvērsts leǵitimācijas mēginājums bija prasība pieškiirt balsstiesības ANO visām savienotajām republikām. Grāmatā atrodama detalizēta šī posma analīze (122.-133. lpp.). 1944. gadā prezidents Rūzvelts uzvarēja prezidenta vēlēšanās un ieguva ceturto mandātu. ASV dienesti, novērojot ASV dzīvojošo lietuviešu balsotāju izvēli, konstatēja vinuu atbalstu Rūzveltam, kaut arī viña solījums, satiekoties ar ASV lietuviešu kopienas pārstāvjiem 1940. gada augustā, proti, ka Lietuvas neatkarība tiks atjaunota pēc Otrā pasaules kara beigām, bija klaji meli (118. lpp.).

Jaltas konferencē Baltijas jautājums netika apspriests. Vienošanās par PSRS pilsoṇu bēgḷu repatriāciju bija nenoteikta attiecībā uz Baltijas valstu pilson,iem: PSRS interpretācija atšķīrās no ASV un Lielbritānijas interpretācijas, kas neapšaubāmi 
izglāba daudzus Baltijas bēg̣̣us no piespiedu repatriācijas (149. lpp.). Monogrāfijā uzsvērts, ka Lielbritānijas varas iestādes baltiešu bēgḷus traktēja kā "bezpavalstniekus", toties ASV - kā attiecīgo valstu pilsoṇus (147. lpp.). ANO dibināšanas konferencē savu vēlmi piedalīties bija pieteikuši Baltijas valstu diplomāti, tomēr nesaṇēma atbildi uz saviem iesniegumiem. Monogrāfijas autors skaidro PSRS atteikšanos no prasības iegūt Lietuvas PSR trešo PSRS savienotās republikas vietu ANO G̦enerālajā asamblejā kā "iespējamas bažas liet ūdeni uz buržuāzisko nacionālistu pozicijām”, kas varēja apdraudēt tikai sākuma posmā esošo Lietuvas PSR padomju pārvaldi (135. lpp.). ASV prezidenta Rūzvelta nāve 1945. gada 12. aprīlī pilnīgi nesagatavotu amatam izvirzijja Hariju Trumenu (Harry Truman). Baltijas jautājumā prezidents Trumens sākotnēji bez grozījumiem turpināja Rūzvelta kursu, respektīvi, amatu saglabāja visi agrākie padomdevēji-ierēdņi. Viņam nācās pakāpeniski iepazīties ar vairākiem prezidenta Rūzvelta slepeniem vienošanās dokumentiem.

\section{Otra pasaules kara izskaṇa, pēckara un aukstā kara laika notikumi}

Pēdējā nodaḷa aptver stipri garu laika posmu, proti, pirmos pēckara gadus, un Baltijas jautājuma faktisko šifrēto (zemteksta) klātbūtni ASV un PSRS attiecībās visā aukstā kara laikā. Šì sadaḷa ir stipri selektīva un nepretendē uz pilnīgu apskatu. Vairākkārt norādīts, ka Lielbritānija drīzāk ir gatava piešḳirt de iure atzišanu (140.-148. lpp.). ASV nostāja Baltijas jautājumā attīstījās pretējā virzienā, un jau 1945. gada septembrī Valsts departaments, neapstrīdot Lielbritānijas nostāju un gatavību piešķirt de iure atzīšanu, jau sākot ar 1945. gada vasaru, tomēr izteica domu, ka Baltijas valstu statusu varēs noteikt vienlaikus ar miera līguma noslēgšanu ar Vāciju (148. lpp.). Šķiet, ka pēdējā iespēja aktualizēt Baltijas valstu jautājumu bija Parīzes miera konference 1946. gadā. Punktu kuluāros izvērstajām diskusijām pielika ASV valsts sekretāra vietas izpildītāja Dīna Ačesona (Dean Acheson, 1893-1971) 1946. gada jūlija nota, norādot, ka ASV interesēs būtu atlikt Baltijas valstu galīga statusa noteikšanu uz laiku, kad tiks noslēgts miera līgums ar (apvienotās) Vācijas civilo valdību (209. lpp.). Pēckara laika sarunās padomju pārstāvji bija izcēlušies ar nepārdomātu nepiekāpību - tas arī nozīmēja, ka vairāki jautājumi netika atrisināti (sk. 31. atsauci 209.-210. 1pp.).

Monogrāfijas autors nedaudz pieskaras Baltijas bēgḷu dzivei okupētās Vācijas Rietumu pārvaldītās zonās (diemžēl nav norādes uz l,oti piekāpīgo Francijas zonas pārvaldes attieksmi pret repatriāciju), fiksējot 1945. gada 14. jūlija militārās pārvaldes pavēli visiem bēgliem, kas dzīvoja Baltijas valstīs 1939. gadā, tikai brīvprātīgi izvēlēties atgriezties mājās (147. lpp.). Autors īsi un neprecīzi izsakās par Rietumu valsts pārvaldes pretimnākšanu PSRS, piel̦aujot aǵitāciju par labu atgriešanos mājās, ar piezīmi, ka padomju pārstāvji izmantoja personīgu šantāžu. Toties nevar piekrist, ka baltiešu (vispār visu Austrumeiropas) bēgl̦u skrīnings tika īstenots, tikai un vienīgi pateicoties padomju pārstāvju spiedienam. Škiet, nepareizs ir apgalvojums, ka Baltijas Universitātē īstenots skrīnings šāda spiediena rezultātā. Nav pareizs apgalvojums, ka Lielbritānijas zonā 1946. gadā tika apturēta baltiešu bēg̣̣u preses darbība, slēgtas organizācijas vai traucēts atbalsts kultūras pasākumiem (149. lpp.). ${ }^{8}$ Interesanti ka šīs nostādnes Pīrimē formulējis, atsaucoties uz Latvijas sūtṇa Londonā Kārḷa Zariṇa 1946. gada iesniegumu Foreign Office (56., 211. lpp.).

Baltijas jautājums tālāk nefigurēja nedz aukstā kara laika akadēmiskos pētījumos, 
nedz starpvalstu attiecībās līdz 20. gadsimta 90. gadiem. $^{9}$ Kā pamatojumu lēmumam tomēr neatzìt de iure Baltijas valstu aneksiju un inkorporāciju autors piekrīt agrāk izskanējušai domai, ka to statuss tika formāli sasaistīts ar miera līguma noslēgšanu ar Vāciju. ${ }^{10}$ Šo līgumu noslēdza tikai 1990. gadā, kad visas trīs Baltijas valstis bija paguvušas paziñot par vēlmi atkal būt suverēna starptautiskās sabiedrības daḷ.

Monogrāfija beidzas ar norādi uz 2005. gada Krievijas prezidenta Vladimira Putina izteicienu par to, ka "PSRS bojāeja bijusi lielākā 20. gadsimta politiskā katastrofa" (161. lpp.). Tas ir atgādinājums, ka Baltijas valstīm jāturpina novērtēt aktuālos izaicinājumus, vispirms labi saprotot 20. gadsimta vēstures nianses.

\section{Baltijas diplomātu un ārzemju kopienu galvenās aktivitātes}

Mulsina fakts, ka šajā laikā kopā aktīvi bija tikai septiņi Baltijas valstu diplomāti (trīs no Igaunijas, divi no Latvijas un viens no Lietuvas) (16. lpp.), kuri centās aizstāvēt savu neatkarīgo valstu intereses. Recenzentam škita interesanti, ka tikai viens Igaunijas diplomāts paklausîja pavēlei atgriezties mājās 1940. gada vasarā (13. lpp.). Saprotams, monogrāfijas autors uzsvēris Igaunijas diplomātu, sevišķi Kārela Pusta (Kaarel Pusta) aktivitātes. Latvijas sūtnis Lielbritānijā Kārlis Zariņš ir pieminēts, bet viṇa pūliṇi nav novērtēti, tas varbūt saprotams, ņemot vērā l, loti minimālo informāciju, kas publicēta angḷu valodā. Uzsvars darbā likts uz Igaunijas pieredzi, proti, izcelti Igaunijas Republikas diplomātu centieni darboties savas valsts interešu aizstāvībā. Autors atzīst, ka ieskatu Latvijas un Lietuvas diplomātu darbībā guvis no šo aktivitāšu atspogul,ojuma Igaunijas diplomātu arhīvu materiālos. Diemžēl aizvien jāgaida šī laika aktivitāšu pētījums, kas būtu balstīts uz līdzvērtīgu visu triju diplomātu grupu arhīvu materiālu izmantošanu un būtu pieejams angḷ valodas akadēmiskām aprindām.

Latvijā pētījumos par Latvijas diplomātu aktivitātēm uzsvērtas 1940. gada 17. maija Latvijas valdības ārkārtējās pilnvaras. Šķiet tomēr, ka Igaunijas diplomāti bez savas valdības ārkārtas pilnvarām spēja rīkoties stipri līdzīgi, kā to varēja darīt Lielbritānijā Kārlis Zariṇš un sūtnis ASV Alfrēds Bīlmanis. K. Pīrimē no saviem pētījumiem daudzos arhīvos secina, ka Baltijas jautājuma risināšanā 1940.-1943. gadā baltiešu diplomātu centieniem nebija redzamas ietekmes uz pieņemtajiem lēmumiem.

Monogrāfijā nodaḷās, kas veltītas starpvaldību sarunām, arī Igaunijas, Latvijas un Lietuvas diplomātu centieniem, pavīd norādes uz ārzemēs dzīvojošo tautiešu atbalstošām aktivitātēm jau Otrā pasaules kara laikā. Recenzents nav atradis akadēmiskus pētījumus par ASV latviešu kopienas politiskām vai publicistiskām aktivitātēm tajā laikā (un arī līdz 20. gadsimta 40. gadu beigām).

Var piekrist Pīrimē, ka igaunu diplomāti raudzījās uz notikumiem daudz vēsāk nekā baltiešu bēgḷi, kuri lika cerības uz kara izcelšanos starp ASV un PSRS. Igaunijas diplomāta Heinriha Lareteja (Heinrich Laretei) publiski paustais uzskats (Zviedrijā jau 1945. gadā, sk. 37. atsauci 210. lpp.), ka bēgḷiem vajadzēs pārṇemt cīṇu par neatkarības atgūšanu (un ne jau militārā ceḷā) liecina par izpratni, ka tas būs garš process. Būtu interesanti izpētīt, vai Latvijas Republikas diplomāti līdzīgā veidā toreiz uzrunāja bēgḷus no Latvijas.

\section{Noslēgums}

Monogrāfijas autors atradis Molotova memuāros nicinošu iesauku tā laika Lielbritānijas ārlietu ministram Antonijam 
İdenam - gḷēevulis (65. lpp.). Varam tikai minēt, kādu iesauku ieguva ASV prezidents Rūzvelts... Toties autora centieni raksturot Čērčilu kā tikai un vienīgi antikomunistu neṇem vērā to, ka Čērčils kā vēsturnieks un savas dižciltīgās gimenes atvase sekoja ilglaicīgai Lielbritānijas oportūnistiskai praksei izmainīt attiecības ar sabiedrotajiem pat kara laikā - pēc izdevības. Lieki atgādināt, ka nedz ASV, nedz Lielbritānijai nebija nekāda juridiski saistoša pienākuma aizstāvēt Baltijas valstis. PSRS vadība no sarunām ar ASV un Lielbritāniju bija sevi pārliecinājusi, ka atguvusi cariskās Krievijas provinces - jo ASV un Lielbritānija neplānoja tās atbrīvot no Vācijas okupācijas un necentās panākt de iure neatzīšanas politikas faktu.

Monogrāfijā ir daudz informācijas, kas noteikti varēs papildināt latviešu valodā pieejamos rakstus par Otrā pasaules kara Rietumu sabiedroto attieksmi pret Baltijas jautājumu. Trimdas laikā uzrakstītie darbi uzsvēra Baltijas valstu nodevības tēmu. Padomju Latvijā prevalēja PSRS slavinošā historiogrāfija, kas atspoguḷoja Padomju Savienības izdarības kā attaisnojamas ar atpakal,ejošu skatījumu. Tas, ka līdz galam neatrisinātais Baltijas jautājums PSRS kremta, tika noliegts, kaut gan tā nebija taisnība. Monogrāfijā citēts 1975. gada 15. augustā V. Molotova kā privātās personas Helsinku Noslēguma akta interpretējums - "Rietumu valstis oficiāli (laikam de iure?) atzinušas mūsu robežas" (160. lpp.). ${ }^{11}$

Monogrāfijas noslēgumā autors izcel, savu atklājumu un secinājumu mūsdienīgo nozīmi. Var tikai piekrist Pīrimē viedoklim (161. lpp.), ka Baltijas valstis ieguva un atguva savu suverenitāti divos laika posmos, kad Krievija bija par vāju, lai tām liegtu to darìt. Zìmīga ir atsauce uz Krievijas Federācijas prezidenta Putina politisko kredo, ka PSRS sabrukums ir bijusi 20. gadsimta lielākā politiskā katastrofa. Izlasot šinī grāmatā pasniegto materiālu par Lielbritānijas, ASV un PSRS sarunām līdz Teherānas konferences slepeno sarunu noslēgumam, recenzentam škiet, ka Baltijas valstis savai pastāvēšanas nepārtrauktībai var pateikties līdz šim vēl nenoskaidrotai "laimīgās lozes" izvilkšanai. Iespējams, J. Staḷins bija pārliecināts, ka Baltijas titulārajās tautās viṇš uz visiem laikiem izdzēsis vēlmi būt suverēnām un neatkarīgām - jo sevišķi tamdēl, ka savos 20 neatkarības gados tās nebija varējušas atrast ciešus sabiedrotos, kuri PSRS būtu bijis jārespektē.

Šîs monogrāfijas lielā starptautiskā redzamība nozīmēs to, ka latviešu un lietuviešu valodā rakstītais paliks paēnā. Nevar pārmest Pīrimē, ka izmantoti igauṇu valodā rakstītie avoti. Savā īsajā recenzijā vācu vēsturnieks Olafs Mertelsmanis (Olaf Mertelsmann) ar novērojumu: "Aufgrund der Sprachbarriere sind lettische oder litauische Positionen weniger stark vertreten als

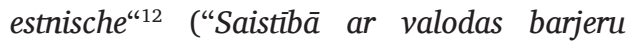
latviešu un lietuviešu pozicijas ir pārstāvētas mazāk") skubināja latviešu un lietuviešu valodas pratējus papildināt angḷu valodas pratēju skatījumu uz Baltijas diplomātu aktivitātēm laika posmā pēc viṇu valstu okupācijas. Nedz sūtnis K. Zariņš, nedz sūtnis A. Bīlmanis nav izpelnījušies Latvijas vēsturnieku uzmanību ar izvērstu akadēmisku pētījumu. Ieskatoties igauņu vēsturnieku veikumā, var izcelt tādu sasniegumu kā grāmata angḷ u valodā par sūtni Tormu ${ }^{13}$ (tās pamatā ir promocijas darbs, kas aizstāvēts 2010. gadā Glāzgovas Universitātē).

Diemžēl viens aspekts no K. Pīrimē iecerēm, kas paustas ievadvārdos, proti, identificēt iemeslu, kamdēḷ Rietumu valstis ar šḳietami tik vieglu roku norakstīja Baltijas valstu pastāvēšanu, ir tikai daḷeji îstenojies. Pēc recenzenta domām, šāds iznākums bija sekas visai vārgai Baltijas valstu interešu aizstāvēšanai no ASV un Lielbritānijas puses, šķietami neievērojot, ka PSRS tīkoja "atjaunot" no Krievijas impērijas 
"aizmukušās sastāvdaḷas". Atklāta pētnieciska tēma ir Baltijas valstu reputācijas izveide pēc neatkarības atzišanas 20. gadsimta 20. gados un šîs reputācijas evolūcija līdz 1939. gadam ${ }^{14}$. Šãdam pētijumam pirmām kārtām meklējamas liecības toreiz vadošo Eiropas valstu (Vācijas, Lielbritānijas, Francijas, arī Zviedrijas) arhīvos un ar šo valstu ārpolitiku saistîtos sekundārajos avotos.

\section{ATSAUCES UN SKAIDROJUMI}

${ }^{1}$ Māra Mantenieka (ASV) recenzija publicēta 08.09.2015. The Washington Post un atrodama internetā: http:// historynewsnetwork.org/article/160474 (skatīts 11.21.2017.). Česlova Laurinavičus recenzija publicēta: Lithuanian Historical Studies 2015, No. 20, pp. 252-259. Pieejams: http:// talpykla.istorija.lt/bitstream/handle/99999/3066/13\%20\%20 REC\%20Laurinavicius\%20LHS\%20 Vol.\%2020\%20p.\%20252-259.pdf?sequence =1\&isAllowed =y (skatīts 21.11.2017.). Vìtauta Petrona recenziju sk.: Vytautas Petronis. [Review] Kaarel Piirimäe, Roosevelt, Churchill, and the Baltic question. Allied relations during the Second World War. In: Journal of Baltic Studies 47, 2016, Issue 1, pp. 155-157.

${ }^{2}$ Par šo grāmatu ziņots un dạ̣a tās satura izmantota rakstā no Latvijas Ārpolitikas institūta krājuma: EDIJS Bošs. A Strategic Appraisal of a Centenary of US-Latvian Relations: The Baltics in American Policy from Wilson to Obama. In: ANDRIS SpRUDS, DIANA POTJOMKINA (eds.). Latvia and the United States: Revisiting a Strategic Partnership in a Transforming Environment. Riga 2016, pp. 20-43. Pieejams: http://www.lai.lv/publikacijas/latvia-and-the-united-states-revisitinga-strategic-partnership -in-a-transforming-environment-514 (skatìts 21.11.2017.).

${ }^{3}$ Piem.: LEV V SostKov (red.). Geopolitika i Pribaltika. Moskva 2010. Šajā materiālā apkopoti Krievijas specdienestu atlasītie dokumenti, arī divi Dr. Tatjanas Volokitinas rediǵêtie krājumi par PSRS un Rietumeiropas attiecībām.

${ }^{4}$ Trīs Valsts departamenta darbinieki, kas bija cieši saistīti kā padomdevēji ar ASV politikas formulēšanu, l̦oti dažādi izteicās pret Baltijas jautājumu. Jau pieminētais Hendersons bija lojāli noskaņots un izpelnījās "izsūtǐšnu" uz Irāku 1943. gadā pēc Maksima Ḷitvinova neoficiāli izteiktā ultimāta, ka Hendersona turpinātās aktivitātes varētu stipri nelabvēlīgi ietekmēt attiecības starp PSRS un ASV (72. lpp.), savukārt Džordžs Kennans (George Kennan) ḷoti nievājoši novērtēja latviešus (33. lpp.), bet Čărlzs Bolens (Charles Bolen) bez ierunas ievēroja prezidenta Rūzvelta līniju Baltijas jautājumā un turpināja to arī pie prezidenta Trumena (149. lpp.).

${ }^{5}$ Pastāv teorija, kuras autors ir ASV vēsturnieks Daniels Jergins (Yergin), ka Valsts departamentā eksistēja tā sauktā Rīgas skola, kurā ietilpa Hendersons, Kenans un Bolens. Šie diplomāti bija strādājuši ASV vēstniecībā Rīgā starpkaru periodā un šai laikā gūtā pieredze lika viņiem būt negatīvi noskaņotiem pret PSRS - zin. red. piez.

${ }^{6}$ Par prezidenta Rūzvelta vilšanos, ka PSRS atteicās izmaksāt kompensāciju, kas bija paredzēta ASV un PSRS līguma par PSRS atzī̌sanu, sk. 34. lpp.

${ }^{7}$ Lielbritānijas vēstnieks PSRS no 1940. gada maija līdz 1942. gadam; viņa pirmais uzdevums konstatēt varbūtību, ka PSRS pieteiktu karu Vācijai. Viņa pārliecība, ka Baltijas valstis pazudušas neatgriezeniski, netieši redzama atskaitē par 1940. gada 18. jūlija tikšanos Maskavā ar Latvijas sūtni PSRS, Frici Kocinu, kur sūtnis nievājoši raksturots: "patikkams mazs vīriňš, kas pārbijies par savas valsts nākotni" (24. lpp.). Šì tikšanās notika pēc tam, kad Kripss satika Molotovu 1940. gada 14. jūnijā un pauda savas valdības gatavību saprast PSRS rīcību ārējo draudu mazināšanai.

${ }^{8}$ Zināmu ieskatu šinī sakarībā var gūt no raksta: LILITA ZAḶKALNE. No repatriācijas līdz kultūras sakariem. In: Jaunā Gaita 46, 2001, Nr. 224, 33.-43. lpp; Jaunā Gaita 46, 2001, Nr. 225, 33.40. lpp.), bet par Displaced Persons (DP) nometnēs dzīvojošo trimdinieku aukstā kara aizsākuma visai klusināto novērtējumu sk.: KĀRLIS KANGERIS. Perception of the Cold War among Latvian exiles and in Latvia 1946-1949/1950 [2016. gada konferences referāts, pieṇemts publicēšanai]. 
Pīrimē būtu ieguvis labāku ieskatu, izmantojot nesen publicēto avotu: GERARD DANIEL CoHEN. In War's Wake: Europe's Displaced Persons in the Postwar Order. New York 2011, 248 p.

9 John Hiden, VAhur MAde, David J. SMith (eds.). The Baltic Question during the Cold War. London 2008, 224 p.

${ }^{10}$ Monogrāfijas autors atsaucas uz 1975. gadā publicēto rakstu: LAWRENCE JUDA. United States' Nonrecognition of the Soviet Union's Annexation of the Baltic States: Politics and Law. In: Journal of Baltic Studies 6, 1975, No. 4, pp. 272-290. Tomēr pagājusi secen atsauce uz trim Ričarda Šnorfa rakstiem žurnālā Lituanus: RICHARD SCHNORF. The Baltic States in US-Soviet relations. In: Lituanus. Lithuanian Quarterly Journal of Arts and Sciences 12, 1966, No. 1, Spring, pp. 33-53; RICHARD SCHNORF. The Baltic States in US - Soviet relations. The Years of Doubt. In: Lituanus. Lithuanian Quarterly Journal of Arts and Sciences 12, 1966, No. 4, Winter; RICHARD SCHNORF. The Baltic States in US - Soviet relations. From Truman to Johnson. In: Lituanus. Lithuanian Quarterly Journal of Arts and Sciences 14, 1968, No. 3, Fall, pp. 43-60. Šie raksti pārklāj laika posmu no 1939. gada līdz ASV prezidenta Lindona Džonsona (1963-1969) administrācijas periodam.

${ }^{11}$ Fragments no Feliksa Čujeva sarunām ar V. Molotovu, kas notika, sākot no 70. gadiem, un noslēdzās īsi pirms Molotova nāves 1986. gadā. Grāmata izdota 1991. gadā krievu valodā, bet iztulkota angliski 1993. gadā. FeLIX CHUEv. Molotov Remembers: Inside Kremlin Politics: Conversations with Felix Chuev. Chicago 1993, 438 p.

${ }^{12}$ Olaf Mertelsmann. [Review]. Kaarel Piirimae. Roosevelt, Churchill, and the Baltic Question. Allied Relations during the Second World War. In: Forschungen zur baltischen Geschichte 10, 2015, pp. 430-432.

${ }^{13}$ Sk. monogrāfiju: TinA TAmman. The last ambassador: August Torma, soldier, diplomat, spy. Amsterdam 2011.

${ }^{14}$ Sk. 2004. gadā Parīzes Universitātē aizstāvēto promocijas darbu: JULIEN GUESLIN. La France et les petits états baltes : réalités baltes, perceptions françaises et ordre européen (1920-1932). Pieejams: https://tel.archives-ouvertes.fr/tel-00126331 (skatīts 06.11.2018.). 